\title{
Artykuły
}

II. PRAWO

Zeszyty Naukowe KUL 60 (2018), nr 2 (242)

\section{Właściwość wojewody w zakresie zapewnienia bezpieczeństwa i porządku publicznego oraz zapobiegania zagrożeniu życia i zdrowia}

\section{Wstęp}

Мojewoda jest powołany do realizowania zadań administracji rządowej

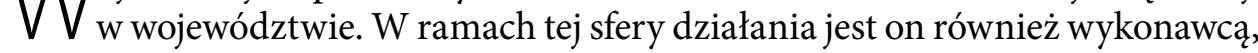
jak też inicjatorem polityki bezpieczeństwa. Polityka ta jest realizowana na wszystkich szczeblach zarządzania, zarówno w terenie, jak też na obszarze całego państwa. Właściwość wojewody, w tym w sprawach bezpieczeństwa, rozciąga się na obszar województwa, zatem jednostki podziału terytorialnego państwa o stosunkowo dużym zasięgu i znaczeniu, dlatego też jego aktywność będzie niezwykle ważna z punktu widzenia przeciwdziałania i zwalczania zagrożeń występujących na terenie regionu.

Właściwość wojewody w zakresie realizacji zadań ochronnych, których celem ostatecznie jest zapewnienie bezpieczeństwa nie wyklucza podejmowania tego rodzaju działań przez inne terenowe organy administracji publicznej - rządowej i samorządowej. Wojewoda wyposażony jest jednak w szerokie instrumentarium służące przeciwdziałaniu zagrożeniom na obszarze województwa oraz usuwaniu ich skutków, posiada także znaczne środki finansowe, które mogą być w tych celach wykorzystane.

Zadania i kompetencje wojewody w zakresie zapewnienia bezpieczeństwa nie mogą godzić w samodzielność samorządu terytorialnego, jako podstawowej

* Dr hab. MirosŁaw Karpiuk, prof. UWM - Katedra Bezpieczeństwa i Porządku Publicznego Wydział Prawa i Administracji UWM; e-mail: miroslaw.karpiuk@uwm.edu.pl 
formy decentralizacji władzy publicznej w państwie. Samorząd terytorialny wykonuje istotną część zadań publicznych, co również dotyczy bezpieczeństwa, a wojewoda może władczo wkraczać w ten obszar wyłącznie w przypadkach przewidzianych przez ustawodawcę i tylko w trybie nadzoru. Terenowy system bezpieczeństwa narodowego jest ukształtowany w sposób umożliwiający wszystkim podmiotom składającym się na strukturę administracji publicznej na poziomie województwa (elementom tego systemu) niezakłócone działanie na rzecz zapewnienia bezpieczeństwa zarówno w oparciu o zasadę samodzielności (samorząd terytorialny a terenowa administracja rządowa), jak też kierownictwa (odrębnie administracja rządowa oraz samorząd terytorialny), czy koordynacji (samorząd terytorialny i terenowa administracja rządowa).

Spośród szeregu zadań o charakterze ochronnym skupiono się na wybranych aspektach bezpieczeństwa i porządku publicznego, w tym dotyczących zarządzania kryzysowego oraz stanów nadzwyczajnych, jak również na kwestiach związanych z zagrożeniami życia i zdrowia. Celem opracowania jest wskazanie mechanizmów kształtujących regionalny system bezpieczeństwa narodowego (charakterystycznych dla sfery bezpieczeństwa i porządku publicznego, czy ochrony życia i zdrowia), w ramach którego prawodawca przyznaje wojewodzie $\mathrm{w}$ zdecydowanym zakresie funkcję kierowniczą

\section{Właściwość wojewody, jako przedstawiciela administracji rządowej, w zakresie zapewnienia bezpieczeństwa i porządku publicznego}

Wojewoda odpowiada za wykonywanie polityki Rady Ministrów w województwie, a w szczególności zapewnia współdziałanie wszystkich organów administracji rządowej oraz samorządowej, które działają na terenie województwa i kieruje ich działalnością w zakresie zapobiegania zagrożeniu życia, zdrowia lub mienia oraz zagrożeniom środowiska, bezpieczeństwa państwa i utrzymania porządku publicznego, ochrony praw obywatelskich, a także zapobiegania klęskom żywiołowym, jak też innym nadzwyczajnym zagrożeniom oraz zwalczania i usuwania ich skutków ${ }^{1}$.

Jednym z elementów wojewódzkiej polityki bezpieczeństwa, realizowanej przez wojewodę, jest zapewnienie w tej sferze współdziałania. Zapewnienie współdziałania jest to dążenie do zagwarantowania takiego działania wielu,

${ }^{1}$ Art. 22 pkt 2 ustawy z dnia 23 stycznia 2009 r. o wojewodzie i administracji rządowej w województwie (t.j. Dz.U. z 2015 r., poz. 525 ze zm.), dalej u.w.a.r. Ustawodawca w art. 22 u.w.a.r. w sposób ogólny określa funkcję reprezentacyjną wojewody odnoszącą się do Rady Ministrów, a jej uszczegółowienie następuje w przepisach materialnych, M. Karpiuk, Zadania i kompetencje zespolonej administracji rządowej w sferze bezpieczeństwa narodowego Rzeczypospolitej Polskiej. Aspekty materialne i formalne, Warszawa 2013, s. 133. 
często niezależnych podmiotów, aby rezultat osiągnięto jak najmniejszym kosztem. W pojęciu tym mieszczą się również działania natury planistycznej, organizacyjnej, motywacyjnej i kontrolnej, które stanowią o istocie funkcji zarządzania. W związku z powyższym należy mieć na uwadze fakt, że cel działania dla każdego $\mathrm{z}$ wykonawców musi być wspólny. Poza zapewnieniem współdziałania wojewoda posiada również kompetencje kierownicze, które są zbieżne $\mathrm{w}$ określonym zakresie $\mathrm{z}$ uprawnieniami wynikającymi $\mathrm{z}$ art. 25 u.w.a.r., ponieważ kierowanie oznacza powodowanie, aby podmiot kierowany zachowywał się z godnie $\mathrm{z}$ wolą podmiotu kierującego, zatem środki władcze są rozleglejsze niż w zakresie wydawania poleceń ${ }^{2}$.

Wojewoda na gruncie art. 22 pkt 2 u.w.a.r. zapewnia współdziałanie wszystkich organów administracji rządowej oraz samorządowej działających w województwie i kieruje ich działalnością $\mathrm{w}$ sprawach $\mathrm{z}$ zakresu bezpieczeństwa i porządku publicznego ${ }^{3}$. W przypadku współdziałania mamy do czynienia $\mathrm{z}$ harmonizacją działań ukierunkowanych na przeciwdziałanie zagrożeniom, czy też na minimalizację oraz usuwanie skutków w przypadku ich powstania. Jeżeli chodzi o kierownictwo wynikające $\mathrm{z}$ art. 22 pkt 2 u.w.a.r., to instytucja ta godzi istotę samorządności terytorialnej, która opiera się na zasadzie samodzielności. Samorząd terytorialny jako struktura wykonująca zadania w imieniu własnym i na własną odpowiedzialność spod kierownictwa administracji rządowej, w tym przypadku wojewody, powinna być wyłączona. Zasada decentralizacji władzy publicznej nie zezwala na ingerencję administracji rządowej dokonywaną w ramach kierownictwa. Podstawową cechą samorządu terytorialnego jest jego niezależność od administracji rządowej, a władcze oddziaływanie tej administracji jest dopuszczalne jedynie w ramach nadzoru, przy uwzględnieniu jedynego kryterium, jakim jest zgodność z prawem, gdy kierownictwo w zdecydowany sposób ogranicza swobodę tej formy decentralizacji.

Wojewoda w sytuacjach nadzwyczajnych, jak wynika z art. 22 pkt 2 u.w.a.r., zapewnia współdziałanie wszystkich organów administracji rządowej i samorządowej działających w województwie i kieruje ich działalnością na zasadach określonych w ustawach szczególnych. Ustawodawca wskazując na tego rodzaju właściwość w tym przepisie nie zawarł żadnych wytycznych co do trybu i zakresu współdziałania oraz kierowania określonymi podmiotami, odsyłając w tym zakresie do ustaw odrębnych. W związku z czym to te ustawy (odrębne), a nie

${ }^{2}$ W. Kitler, [w:] M. Czuryk, M. Karpiuk, M. Mazuryk (red.), Ustawa o wojewodzie i administracji rządowej w województwie. Komentarz, Warszawa 2012, s. 90-91.

${ }^{3}$ Elementem zapewniającym współdziałanie organów administracji publicznej w zakresie zapobiegania zagrożeniom występującym w terenie jest działanie wojewódzkich zespołów zarządzania kryzysowego, które skupiają przedstawicieli samorządu terytorialnego i administracji rządowej, M. Pacak, [w:] M. Pacak, K. Zmorek, Ustawa o wojewodzie i administracji rządowej w województwie. Komentarz, Warszawa 2013, s. 77. 
u.w.a.r., będą umożliwiały podjęcie określonych tam działań, a art. 22 pkt 2 u.w.a.r. będzie jedynie wskazówką, że takie uprawnienia mogą być na gruncie ustawowych przepisów szczególnych przewidziane. Należy zatem podkreślić, że art. 22 pkt 2 u.w.a.r. nie stanowi wystarczającej podstawy do podjęcia określonych czynności przez wojewodę w zakresie zapobiegania nadzwyczajnym zagrożeniom oraz zwalczania i usuwania ich skutków, które to czynności miałyby mieć miejsce w ramach współdziałania i kierowania określonymi w tym przepisie podmiotami.

Ustawodawca w art. 25 ust. 1 u.w.a.r. zezwala wojewodzie na wydawanie poleceń, które obowiązują wszystkie organy administracji rządowej działające w województwie, a w sytuacjach nadzwyczajnych, do których odnosi się art. 22 pkt 2 u.w.a.r., obowiązujące również organy samorządu terytorialnego, przy czym o wydanych poleceniach wojewoda niezwłocznie informuje właściwego ministra ${ }^{4}$. Wydawanie poleceń, jeżeli chodzi o administrację rządową, nie budzi większych zastrzeżeń, ponieważ administracja ta została ukształtowana w oparciu o zasadę hierarchicznego podporządkowania, gdzie polecenia są powszechnie stosowanym środkiem oddziaływania. Inaczej jest jednak w relacjach wojewoda - samorząd terytorialny, które to relacje w przypadku możliwości zastosowania instrumentarium ingerencyjnego opierają się na nadzorze. Jedynym kryterium tego nadzoru jest zgodność z prawem działania organu nadzorowanego i tylko pod tym kontem można oceniać działalność samorządu terytorialnego, która może być następnie korygowana przez wojewodę. Ze względu na konstytucyjnie gwarantowaną zasadę samodzielności samorządu terytorialnego, nawet w przypadku sytuacji nadzwyczajnych, polecenia nie należą do instrumentów, za pośrednictwem których wojewoda może władczo oddziaływać na samorząd terytorialny. W związku z czym rozwiązanie przyjęte $\mathrm{w}$ art. 25 ust. 1 u.w.a.r. należy ocenić negatywnie.

Sytuacje nadzwyczajne, w związku z którymi na gruncie art. 25 ust. 1 u.w.a.r. wojewodzie przysługuje uprawnienie wydawania poleceń, to również sytuacje kryzysowe. W myśl definicji legalnej jako sytuację kryzysową należy rozumieć sytuację, która negatywnie wpływa na poziom bezpieczeństwa ludzi, mienia w znacznych rozmiarach lub środowiska, wywołując znaczne ograniczenia w działaniu właściwych organów administracji publicznej ze względu na nieadekwatność posiadanych sił i środków5. Analiza pojęcia „sytuacja kryzysowa”

${ }^{4}$ Zob. także: W. Lis, Bezpieczeństwo wewnętrzne i porządek publiczny jako sfera działania administracji publicznej, Lublin 2015, s. 235-236. Art. 25 u.w.a.r. nie powinien być poddawany szerszej interpretacji, na skutek której wojewoda byłby uprawniony do wydawania poleceń służących zapobieganiu możliwych do przewidzenia zagrożeń, a nie tylko w sytuacjach nadzwyczajnych, w których do zagrożenia już doszło, M. Polinceusz, [w:] M. Czuryk, M. Karpiuk, M. Mazuryk (red.), Ustawa..., s. 107.

${ }^{5}$ Art. 3 pkt 1 ustawy z dnia 26 kwietnia 2007 r. o zarządzaniu kryzysowym (t.j. Dz.U. z 2017 r., poz. 209 ze zm.), dalej u.z.k. 
pozwala na wskazanie potencjalnych rodzajów zagrożeń, które są przedmiotem zarządzania kryzysowego ${ }^{6}$. Nie wystarcza to jednak do wyczerpującego opisania sytuacji kryzysowej, gdyż zagrożenia z art. 3 pkt 1 u.z.k. określone są w sposób ogólny, a pojęcia mające uszczegółowić ich wymiar, takie jak: „znaczne rozmiary”, „znaczne ograniczenia” pozostawiają również „znaczny” margines swobody w zakresie dokonania oceny, czy mamy do czynienia z sytuacją kryzysową, czy też nie, co dotyczy również pojęcia „nieadekwatność". Istnieje zatem niebezpieczeństwo nadużywania instytucji sytuacji kryzysowej, dla realizacji interesów politycznych a nie dla celów, dla których została ona wprowadzona, zatem dla zapewnienia bezpieczeństwa i porządku publicznego.

Kompetencje wojewody dotyczące wydawania poleceń, w tym odnoszących się do sytuacji nadzwyczajnych, ulegają pewnym ograniczeniom, które wprowadza art. 25 ust. 2 u.w.a.r. Nie mogą one dotyczyć rozstrzygnięć co do istoty sprawy załatwianej w drodze decyzji administracyjnej, jak również czynności operacyjno-rozpoznawczych, dochodzeniowo-śledczych oraz czynności z zakresu ścigania wykroczeń. W związku z powyższym wojewoda nie może wpływać za pośrednictwem poleceń na merytoryczne rozstrzygnięcie sprawy administracyjnej, oraz wyraźnie przewidziane $\mathrm{w}$ tym przepisie czynności prowadzone m.in. w zakresie bezpieczeństwa i porządku publicznego.

Organ niezespolonej administracji rządowej, który otrzymał polecenie od wojewody, w tym w zakresie sytuacji nadzwyczajnych, we własnym zakresie nie może odmówić wykonania polecenia, wówczas, na podstawie art. 25 ust. 3 u.w.a.r. właściwy minister może wstrzymać wykonanie tych pleceń i wystąpić $\mathrm{z}$ wnioskiem do Prezesa Rady Ministrów o rozstrzygnięcie sporu, przedstawiając jednocześnie stanowisko w sprawie.

\section{Właściwość wojewody w zakresie zarządzania kryzysowego}

W sprawach z zakresu zarządzania kryzysowego na terenie województwa, co wynika $\mathrm{z}$ art. 14 ust. 1 u.z.k., właściwy jest wojewoda ${ }^{7}$. W związku z tak określoną właściwością wojewody organy samorządu województwa będą miały ograniczony wpływ na sferę zarządzania kryzysowego na zawiadywanym obszarze, ponieważ to wojewoda będzie głównym decydentem w regionie w przedmiotowym zakresie, a samorząd województwa będzie pełnił jedynie rolę wspierającą.

Ustawodawca w art. 14 ust. 2 u.z.k. zawarł katalog zadań wojewody w sprawach zarządzania kryzysowego, który obejmuje: 1) kierowanie monitorowa-

${ }^{6}$ Wyrok WSA z dnia 8 lipca 2014 r., V SA/Wa 1122/14, LEX Nr 1562927.

7 Przepis ten potwierdza właściwość wojewody w zakresie zarządzania kryzysowego wykonywanego na obszarze województwa, M. Pawełczyk, P. Sokal, Ustawa o zarządzaniu kryzysowym. Komentarz, Warszawa 2014, s. 163. 
niem, planowaniem ${ }^{8}$, reagowaniem oraz usuwaniem skutków zagrożeń na terenie województwa; 2) realizację zadań z zakresu planowania cywilnego; 3) zarządzanie, organizowanie oraz prowadzenie szkoleń, ćwiczeń i treningów z zakresu zarządzania kryzysowego; 4) wnioskowanie o użycie pododdziałów lub oddziałów Sił Zbrojnych Rzeczypospolitej Polskiej; 5) wykonywanie przedsięwzięć, które wynikają z dokumentów planistycznych wykonywanych w ramach planowania operacyjnego realizowanego na terenie województwa; 6) zapobieganie, przeciwdziałanie i usuwanie skutków zdarzeń o charakterze terrorystycznym; 7) współdziałanie z Szefem Agencji Bezpieczeństwa Wewnętrznego w zakresie zapobiegania, przeciwdziałania oraz usuwania skutków zdarzeń o charakterze terrorystycznym; 7) organizację wykonania zadań z zakresu ochrony infrastruktury krytycznej ${ }^{9}$. Z punktu widzenia zakresu realizowanych przez wojewodę zadań wynikających ze sfery zarządzania kryzysowego należy podkreślić jego istotną rolę w przestrzeni bezpieczeństwa, $w$ tym w przypadku wystąpienia sytuacji kryzysowych. Należy również zwrócić uwagę na jego funkcję kierowniczą $w$ sferze zarządzania kryzysowego, co pozwala na efektywną walkę z zagrożeniami występującymi na obszarze województwa, jak też na koordynowanie działań administracji publicznej będących reakcją na sytuację kryzysową, czy też w zakresie usuwania jej skutków. Istotne znaczenie z punktu widzenia zapewnienia bezpieczeństwa mają nie tylko zadania wykonywane ex post, zatem w przypadku, gdy mamy już do czynienia z zagrożeniem i jego skutkami, ponieważ nie mniej ważne są czynności prewencyjne, więc ex ante, za pośrednictwem których można byłoby ewentualnie nie dopuścić do powstania sytuacji kryzysowej. Administracja publiczna bardzo często zadania zapobiegawcze bagatelizuje, licząc na to, że zagrożenie nie powstanie, co z punktu widzenia jej misyjności jest niedopuszczalne.

Zadania z zarządzania kryzysowego realizowane przez wojewodę, ze względu na ich znaczenie dla społeczności regionalnej wykonywane są też w ramach współpracy. Na tę współpracę wskazuje art. 14 ust. 5 u.z.k., stanowiąc, że zadania w powyższym zakresie wojewoda wykonuje we współpracy $\mathrm{z}$ właściwymi organami administracji publicznej. W myśl tego przepisu współpraca obejmuje organy administracji publicznej właściwe w sprawach bezpieczeństwa i ratownictwa. Jako podmiot współpracy wskazuje się tutaj wyłącznie na administrację publiczną, która ma obowiązek zapewnić bezpieczeństwo i porządek publiczny, co nie wyklucza jednak kooperacji z organizacjami pozarządowymi, których

${ }^{8}$ W zakresie działalności planistycznej wojewody zob. zarządzenie Nr 23 Ministra Administracji i Cyfryzacji z dnia 13 grudnia 2013 r. w sprawie wytycznych do wojewódzkich planów zarządzania kryzysowego (Dz.Urz.MC. z 2013 r., poz. 36).

9 Zob. także K. Dunaj, Zarządzanie kryzysowe na poziomie wojewódzkim, [w:] M. Czuryk, K. Dunaj, M. Karpiuk, K. Prokop, Prawo zarządzania kryzysowego. Zarys systemu, Olsztyn 2016, s. 68-69. 
cele statutowe dotyczą przeciwdziałania zagrożeniom. Należy jednak pamiętać że zarządzanie kryzysowe, jako instytucja prawna to określona działalność administracji publicznej.

Ustawodawca w u.z.k. jakby zapomniał o roli podmiotów niepublicznych, $\mathrm{w}$ tym organizacji społecznych w dążeniu do zapewnienia bezpieczeństwa. Bardzo często jest tak, że to sami obywatele i ich organizacje lepiej potrafią sobie radzić $\mathrm{z}$ zagrożeniem i szybciej na nie reagować niż sformalizowana administracja publiczna, a w przypadku sytuacji kryzysowych pokłada się nadzieje zasadniczo wyłącznie na tych strukturach. System zarządzania kryzysowego oparty wyłącznie na administracji publicznej, a taka idea wydaje się wynikać z przepisów u.z.k., jest nie tylko niekompletny, ale też wadliwy i szkodliwy. Pomija podstawowy czynnik ochronny, jakim jest samopomoc i wsparcie organizacji społecznych. Administracja publiczna bez wsparcia podmiotów nieadministracyjnych w niektórych sytuacjach nie jest w stanie skutecznie interweniować i chronić osób, instytucji i mienia.

W art. 14 ust. 6 u.z.k. oraz art. 14 ust. 8 u.z.k. wymienia się zadania odpowiednio komórki organizacyjnej właściwej w sprawach zarządzania kryzysowego w urzędzie wojewódzkim oraz wojewódzkiego zespołu zarządzania kryzysowego. Są to struktury pomocnicze wojewody w sprawach z zakresu zarządzania kryzysowego. Zadania powinny być przypisane bezpośrednio organowi, w tym przypadku wojewodzie, a nie aparatowi pomocniczemu obsługującemu go. Zarówno komórka organizacyjna właściwa w sprawach zarządzania kryzysowego usytuowana w urzędzie wojewódzkim, jak też wojewódzki zespół zarządzania kryzysowego wspierają jedynie wojewodę w wykonywaniu jego zadań, nie powinny legitymować się zatem własnymi zadaniami i kompetencjami, gdyż struktury te nie mają charakteru samoistnego, zostały utworzone do obsługi organu i dokonują tych czynności w ramach zadań i kompetencji tegoż organu.

System wsparcia wojewody w sferze zarządzania kryzysowego na szczeblu regionu ma charakter rozbudowany, a jego elementem, obok komórki organizacyjnej właściwej w sprawach zarządzania kryzysowego w urzędzie wojewódzkim oraz wojewódzkiego zespołu zarządzania kryzysowego jest również wojewódzkie centrum zarządzania kryzysowego.

W województwie, podobnie jak i w pozostałych jednostkach zasadniczego podziału terytorialnego państwa, w zakresie zarządzania kryzysowego duże znaczenie przypisuje się działalności planistycznej, zatem ważne będzie opracowywanie i aktualizowanie wojewódzkiego planu zarządzania kryzysowego składającego się z planu głównego, zespołu przedsięwzięć na wypadek sytuacji kryzysowych oraz załączników. Wojewódzki plan zarządzania kryzysowego ma charakter diagnostyczny, w szczególności zawiera on opis zagrożeń oraz prawdopodobieństwo ich wystąpienia, zadania i kompetencje administracji publicznej w zakresie zarządzania kryzysowego, określenie wielkości posiada- 
nych sił i środków oraz tryb ich uruchamiania, a także wykaz podejmowanych czynności na wypadek wystąpienia opisanych tam okoliczności.

\section{Właściwość wojewody w czasie stanów nadzwyczajnych}

Ze względu na szczególne, kwalifikowane zagrożenia bezpieczeństwa i porządku publicznego mogą być wprowadzane stany nadzwyczajne. W czasie tych stanów również wojewoda będzie zobowiązany do podejmowania określonych działań ochronnych (w czasie stanu wojennego - obronnych).

W przypadku wprowadzenia stanu wyjątkowego na obszarze lub części obszaru jednego województwa, działania, które mają przywrócić konstytucyjny ustrój państwa, bezpieczeństwo obywateli lub porządek publiczny, a w szczególności koordynację oraz kontrolę funkcjonowania administracji rządowej i samorządowej, wykonuje wojewoda ${ }^{10}$. W związku $\mathrm{z}$ tak ukształtowaną sferą właściwości wojewody, należy wskazać, że w przypadku obowiązywania stanu wyjątkowego na obszarze nie większym niż województwo, to wojewoda jest tym organem, który w związku z istniejącym zagrożeniem ma przywrócić bezpieczeństwo i porządek publiczny. W przypadku realizacji tego zadania ustawodawca wyposaża go w stosowne, w zdecydowanym zakresie władcze, instrumentarium. W ramach właściwości wojewody wyróżnić należy koordynację oraz kontrolę funkcjonowania administracji rządowej i samorządowej, działającej na obszarze województwa. Działania wojewody mają jednak zmierzać do realizacji celów ustawowych, zatem m.in. do zapewnienia bezpieczeństwa i porządku publicznego, nie może on zatem wykorzystywać instytucji koordynacji oraz kontroli, które wymienia art. 9 u.s.w., do celów politycznych.

Według art. 22 ust. 2 u.s.w., jeżeli stan wyjątkowy został wprowadzony na terenie jednego województwa lub jego części, wojewoda określa, w formie rozporządzeń, szczegółowy tryb oraz sposoby, jak też obszarowy, podmiotowy i przedmiotowy zakres wprowadzenia i stosowania ograniczeń wolności i praw człowieka i obywatela ustalonych przez Prezydenta RP w rozporządzeniu o wprowadzeniu stanu wyjątkowego, czy też rozporządzeniu o przedłużeniu czasu trwania stanu wyjątkowego, uwzględniając przy tym w możliwym stopniu minimalizację indywidualnych oraz społecznych uciążliwości, które wynikają ze stosowania tych ograniczeń. Rozporządzenia wojewody są źródłami prawa powszechnie obowiązującego na obszarze województwa. Ze względu na ingerencyjny charakter norm zawartych w rozporządzeniu, które odnoszą się do ograniczeń wolności i praw człowieka i obywatela, wojewoda nie może ich wpro-

${ }^{10}$ Art. 9 ustawy z dnia 21 czerwca 2002 r. o stanie wyjątkowym (t.j. Dz.U. z 2016 r., poz. 886), dalej u.s.w. 
wadzać w sposób dowolny. Nie mogą one naruszać zasady proporcjonalności, zgodnie z którą dolegliwości mają być minimalne i jednocześnie pozwalające na realizację uprzednio założonego celu, jakim jest w tym przypadku przywrócenie bezpieczeństwa i porządku publicznego.

W czasie stanu klęski żywiołowej działaniami prowadzonymi w celu zapobieżenia skutkom klęski żywiołowej lub ich usunięcia kieruje wojewoda, jeżeli stan klęski żywiołowej wprowadzono na obszarze więcej niż jednego powiatu wchodzącego w skład województwa ${ }^{11}$.

Na podstawie art. 11 ust. 1 u.s.k.ż. wojewoda, w czasie stanu klęski żywiołowej kieruje działaniami, które są prowadzone w celu zapobieżenia skutkom klęski żywiołowej lub ich usunięcia na obszarze województwa. W zakresie realizacji powyższej funkcji, jak wynika $\mathrm{z}$ art. 11 ust. 2 u.s.k.ż., wojewodzie są podporządkowane organy i jednostki organizacyjne administracji rządowej i samorządu województwa działające na obszarze województwa oraz inne siły i środki wydzielone do jego dyspozycji i skierowane do wykonywania tych działań na obszarze województwa, w tym pododdziały i oddziały Sił Zbrojnych RP. Wojewoda nie jest jednak uprawniony do kierowania podmiotami zdecentralizowanymi, również gdy zachodzi konieczność zapewnienia bezpieczeństwa. $Z$ konstytucyjnego punktu widzenia takie władcze ingerowanie w sferę samodzielności samorządu terytorialnego jest niedopuszczalne, nawet jeżeli przeciwdziałanie zagrożeniom i usuwanie ich skutków wymaga takich działań. Zmiany, w tym konstytucyjne w tym zakresie wydaje się, że są konieczne, muszą one zmierzać w kierunku zwiększenia efektywności działań na rzecz bezpieczeństwa, nie mogą jednak dawać wojewodzie zbyt szerokich kompetencji, a tylko takie, które są niezbędne $\mathrm{w}$ walce $\mathrm{z}$ zagrożeniami, gdy w inny sposób bezpieczeństwo nie będzie mogło być zapewnione, bądź przywrócone.

$\mathrm{W}$ art. 11 ust. 4 u.s.k.ż. przewiduje się tryb, który jest uruchamiany, gdy wojewoda nie będzie się należycie wywiązywał z ustawowych obowiązków w zakresie zapobieżenia skutkom klęski żywiołowej lub ich usunięcia. W związku z czym, w razie niezdolności do kierowania lub niewłaściwego kierowania takimi działaniami właściwy minister, może zawiesić uprawnienia wojewody oraz wyznaczyć pełnomocnika do kierowania nimi. Niezdolność do kierowania lub niewłaściwe kierowanie działaniami w zakresie zapobieżenia skutkom klęski żywiołowej lub ich usunięcia automatycznie nie pociąga za sobą zastosowania instrumentarium władczego w postaci zawieszenia uprawnień wojewody i wyznaczenia pełnomocnika. Jest to pozostawione uznaniu właściwego ministra (ministrem tym według art. 8 ust. 4 u.s.k.ż. jest minister właściwy do spraw administracji publicznej lub inny minister, do zakresu działania którego należy zapobieganie

${ }^{11}$ Art. 8 pkt 3 ustawy z dnia 18 kwietnia 2002 r. o stanie klęski żywiołowej (t.j. Dz.U. z 2014 r., poz. 333 ze zm.), dalej u.s.k.ż. 
skutkom danej klęski żywiołowej lub ich usuwanie, a w przypadku wątpliwości co do właściwości ministra, bądź też w przypadku gdy właściwych jest kilku ministrów - minister wyznaczony przez Prezesa Rady Ministrów). Wydaje się jednak, że z punktu widzenia zagrożeń, które determinują wprowadzenie stanu klęski żywiołowej, nieudolność w wykonywaniu ustawowych zadań w tym zakresie może mieć daleko idące skutki, zatem minister powinien skorzystać ze swoich uprawnień, aby możliwie szybko zaprowadzić pożądany ład. Jeżeli minister zdecyduje się na zawieszenie tego rodzaju uprawnień kierowniczych, którymi dysponuje wojewoda, to musi jednocześnie wyznaczyć pełnomocnika. Ustawodawca w przedmiocie wyznaczenia pełnomocnika pozostawia ministrowi znaczną swobodę.

Jak wynika $z$ art. 23 ust. 1 pkt 3 u.s.k.ż. niezbędne ograniczenia wolności i praw człowieka i obywatela, w granicach dopuszczonych w rozporządzeniu Rady Ministrów o wprowadzeniu stanu klęski żywiołowej, o ile stan ten wprowadzono na obszarze więcej niż jednego powiatu wchodzącego w skład województwa, wprowadza wojewoda w drodze rozporządzenia albo decyzji. Ograniczenia wolności i praw człowieka i obywatela muszą być konieczne ze względu na zagrożenia skutkujące wprowadzeniem stanu klęski żywiołowej oraz proporcjonalne, zatem nie mogą być bardziej dolegliwe, niż to jest niezbędne z punktu widzenia realizacji celu w związku z którym zostały one wprowadzone. Wojewoda wprowadza te ograniczenia, albo $\mathrm{w}$ formie aktu prawa miejscowego, albo też w formie aktu administracyjnego. Jeżeli zachodzi potrzeba generalnego, obowiązującego na obszarze województwa lub jego części, ograniczenia wolności i praw człowieka i obywatela, wówczas wojewoda wydaje rozporządzenie, zaś w przypadku konieczności indywidualizacji, wydaje on decyzję administracyjną. Kompetencje wynikające $\mathrm{z}$ art. 23 ust. 1 pkt 3 u.s.k.ż. przysługują wojewodzie wyłącznie, gdy stan klęski żywiołowej został przez Radę Ministrów wprowadzony, występowanie nawet szczególnych zagrożeń nie jest wystarczającą przesłanką zastosowania tego przepisu, gdy ten stan nadzwyczajny nie został wprowadzony.

Rozporządzenia wojewody wydane w sprawie ograniczenia wolności i praw człowieka i obywatela w czasie stanu klęski żywiołowej podlegają ogłoszeniu przez rozplakatowanie obwieszczeń w miejscach publicznych lub w inny sposób miejscowo przyjęty, a także przez ogłoszenie w lokalnej prasie, co wynika z art. 23 ust. 2 u.s.k.ż. Powyższy, szczególny tryb ogłoszenia aktu prawa miejscowego, który wynika $z$ konieczności, aby jego treść dotarła do jak najszerszego grona odbiorców, co z kolei jest bezpośrednio związane z zagrożeniem i jego skutkami, nie zwalnia wojewody z obowiązku ogłoszenia rozporządzenia w urzędowym publikatorze, jakim jest wojewódzki dziennik urzędowy.

W czasie stanu wojennego wojewoda kieruje realizacją zadań obronnych, a także obroną cywilną na obszarze województwa. 
W celu realizacji zadań państwa, które polegają na zapewnieniu pomocy każdej osobie znajdującej się w stanie nagłego zagrożenia zdrowotnego utworzony został system Państwowe Ratownictwo Medyczne ${ }^{12}$. Nagłe zagrożenie zdrowotne można uznać za sytuację nadzwyczajną, zwłaszcza, gdy dotyczy większej liczby osób. Do zadań wojewody na gruncie art. 19 ust. 2 u.PRM należy planowanie, organizowanie, koordynowanie tego systemu, a także nadzór nad nim na terenie województwa. W związku z tak określoną właściwością wojewody należy stwierdzić, że realizuje on istotne zadania w zakresie zapewnienia pomocy osobom znajdującym się w stanie nagłego zagrożenia zdrowotnego. Treść tego przepisu precyzuje zakres kompetencji oraz odpowiedzialności wojewody w przedmiocie wykonywania zadań systemu na terenie województwa. Właściwość wojewody została określona w postaci zamkniętego katalogu obejmującego: planowanie, organizowanie, koordynowanie i nadzór nad systemem na terenie województwa. Rozwinięcie oraz uszczegółowienie dość ogólnie sformułowanych kompetencji wojewody zawierają kolejne przepisy u.PRM ${ }^{13}$.

Jak wynika $\mathrm{z}$ art. 30 u.PRM w przypadku wystąpienia katastrof naturalnych ${ }^{14}$ i awarii technicznych ${ }^{15}$ lub gdy w ocenie lekarza koordynatora ratownictwa medycznego skutki zdarzenia mogą spowodować stan nagłego zagrożenia zdrowotnego znacznej liczby osób, lekarz ten informuje niezwłocznie wojewodę o potrzebie postawienia w stan podwyższonej gotowości wszystkich, bądź też niektórych podmiotów wykonujących działalność leczniczą a działających na terenie województwa. W tym przypadku wojewoda może nałożyć na podmioty wykonujące działalność leczniczą obowiązek pozostawania w stanie podwyższonej gotowości w celu przyjęcia osób znajdujących się w stanie nagłego zagrożenia zdrowotnego, co czyni w drodze decyzji administracyjnej. Decyzji tej nadawany jest rygor natychmiastowej wykonalności. Przepis ten odnosi się

12 Art. 1 ustawy z dnia 8 września 2006 r. o Państwowym Ratownictwie Medycznym (t.j. Dz.U. z 2016 r., poz. 1868 ze zm.), dalej u.PRM.

${ }_{13}$ M. Waszkiewicz, [w:] S. Poździoch (red.), Ustawa o państwowym ratownictwie medycznym. Komentarz, Warszawa 2013, s. 200.

${ }^{14}$ Poprzez katastrofę naturalną rozumieć należy zdarzenie związane z działaniem sił natury, w szczególności wyładowania atmosferyczne, wstrząsy sejsmiczne, silne wiatry, intensywne opady atmosferyczne, długotrwałe występowanie ekstremalnych temperatur, osuwiska ziemi, pożary, susze, powodzie, zjawiska lodowe na rzekach i morzu oraz jeziorach i zbiornikach wodnych, masowe występowanie szkodników, chorób roślin lub zwierząt albo chorób zakaźnych ludzi albo też działanie innego żywiołu, art. 3 pkt 2 ustawy z dnia 18 kwietnia 2002 r. o stanie klęski żywiołowej (t.j. Dz.U. z 2014 r., poz. 333 ze zm.), dalej u.s.k.ż. Zob. także wyrok WSA z dnia 2 lipca 2010 r., I SA/Kr 985/09, LEX Nr 616450.

${ }^{15}$ Jako awarię techniczną rozumieć należy gwałtowne, nieprzewidziane uszkodzenie lub zniszczenie obiektu budowlanego, urządzenia technicznego lub systemu urządzeń technicznych powodujące przerwę w ich używaniu lub utratę ich właściwości, art. 3 pkt 3 u.s.k.ż. 
do warunków nadzwyczajnych, a jego stosowanie należy rozpatrywać w kategoriach okoliczności wykraczających poza normalne funkcjonowanie systemu ratownictwa medycznego ${ }^{16}$. Ustawodawca normuje w tym przepisie działania, które są podejmowane w przypadku sytuacji nadzwyczajnej, która wynika $z$ katastrofy naturalnej lub awarii technicznej, bądź też zdarzenia powodującego stan nagłego zagrożenia zdrowotnego znacznej liczby osób. Podmiotem ochrony będą ludzie znajdujący się w stanie nagłego zagrożenia zdrowotnego.

Wojewoda ogłasza i odwołuje stan zagrożenia epidemicznego lub stan epidemii na obszarze województwa, co czyni w drodze rozporządzenia, na wniosek państwowego wojewódzkiego inspektora sanitarnego ${ }^{17}$. Stan zagrożenia epidemicznego, według art. 2 pkt 23 u.z.z.z. oznacza sytuację prawną wprowadzoną na danym obszarze w związku z ryzykiem wystąpienia epidemii, $w$ celu podjęcia ustawowo określonych działań zapobiegawczych. Z kolei według art. 2 pkt 22 u.z.z.z. stan epidemii to sytuacja prawna wprowadzona na danym obszarze $\mathrm{w}$ związku $\mathrm{z}$ wystąpieniem epidemii $\mathrm{w}$ celu podjęcia określonych w u.z.z.z. działań przeciwepidemicznych i zapobiegawczych dla zminimalizowania skutków epidemii. Jako epidemię ustawodawca rozumie wystąpienie na danym obszarze zakażeń lub zachorowań na chorobę zakaźną w liczbie wyraźnie większej niż we wcześniejszym okresie albo wystąpienie zakażeń lub chorób zakaźnych dotychczas niewystępujących, co wynika $\mathrm{z}$ art. 2 pkt 9 u.z.z.z.

$\mathrm{W}$ rozporządzeniu w sprawie ogłoszenia stanu zagrożenia epidemicznego lub stanu epidemii wojewoda może ustanowić: 1) czasowe ograniczenie określonego sposobu przemieszczania się; 2) czasowe ograniczenie lub zakaz obrotu i używania określonych przedmiotów lub produktów spożywczych; 3) czasowe ograniczenie funkcjonowania określonych instytucji lub zakładów pracy; 4) zakaz organizowania widowisk i innych zgromadzeń ludności; 5) obowiązek wykonania określonych zabiegów sanitarnych, jeżeli wykonanie ich wiąże się z funkcjonowaniem określonych obiektów produkcyjnych, usługowych, handlowych lub innych obiektów; 6) nakaz udostępnienia nieruchomości, lokali, terenów i dostarczenia środków transportu do działań przeciwepidemicznych przewidzianych planami przeciwepidemicznymi; 7) obowiązek przeprowadzenia szczepień ochronnych oraz grupy osób podlegające tym szczepieniom, rodzaj przeprowadzanych szczepień ochronnych, jak stanowi art. 46 ust. 4 u.z.z.z. Rozporządzenie to zawiera przepisy porządkowe, które ograniczają wolności i prawa człowieka i obywatela, jak też swobody, które przysługują innym podmiotom, $\mathrm{w}$ tym przedsiębiorcom. W związku $\mathrm{z}$ ingerencyjnym charakterem rozporządzenia i daleko posuniętym dolegliwościom wynikającym z jego treści

${ }_{16}$ T. Filarski, E. Fryźlewicz-Chrapisińska, M. Waszkiewicz, [w:] S. Poździoch (red.), Ustawa..., s. 266.

${ }^{17}$ Art. 46 ust. 1 ustawy z dnia 5 grudnia 2008 r. o zapobieganiu oraz zwalczaniu zakażeń i chorób zakaźnych u ludzi (t.j. Dz.U. z 2016 r., poz. 1866 ze zm.), dalej u.z.z.z. 
należy je stosować z rozwagą, w ostateczności, gdy za pośrednictwem innych środków (mniej dolegliwych) nie da się zapewnić należytej ochrony. Wojewoda wydając rozporządzenie musi uwzględnić drogi szerzenia się zakażeń i chorób zakaźnych oraz sytuację epidemiczną na obszarze, na którym ogłoszono stan zagrożenia epidemicznego lub stan epidemii. Nie ma zatem dowolności w zakresie kształtowania przestrzeni zapobiegania zagrożeniu życia i zdrowia zarówno w drodze rozporządzeń porządkowych, jak i w przypadku stosowania innych form oddziaływania. Wojewoda jest związany przepisami prawa, które zarówno stanowią podstawę jego działania, jak też wytyczają granice tych działań.

Ustawodawca w art. 46 ust. 5 u.z.z.z. przewiduje szczególny tryb ogłaszania i wejścia w życie rozporządzenia w sprawie ogłoszenia stanu zagrożenia epidemicznego lub stanu epidemii. Jest ono niezwłocznie ogłaszane w odpowiednim dzienniku urzędowym (wojewódzkim) i wchodzi w życie z dniem ogłoszenia. Taki tryb został wprowadzony ze względu na status zagrożenia i konieczność szybkiego podjęcia adekwatnych środków ochronnych. Oczywiste jest, że zakażenia i choroby zakaźne u ludzi zagrażają ich zdrowiu i życiu, w związku z czym wojewoda ma obowiązek przeciwdziałać im, w tym w drodze rozporządzeń porządkowych. Nie może jednak nadużywać tej formy prawnej, która służy zapewnieniu bezpieczeństwa zdrowotnego.

Ze względu na ingerencyjność rozporządzenia porządkowego w sprawie ogłoszenia stanu zagrożenia epidemicznego lub stanu epidemii, a także zapoznanie jak największej grupy osób z jego treścią, w art. 46 ust. 6 u.z.z.z. wprowadza się obowiązek poinformowania obywateli o obowiązkach wynikających z przepisów tego aktu powszechnie obowiązującego na obszarze województwa, w sposób zwyczajowo przyjęty na danym terenie. Ustawodawca nie określa w jaki sposób wojewoda ma przekazać regionalnej społeczności, czy też osobom, które mogą znaleźć się na terenie województwa, informacje dotyczące nałożonych w formie rozporządzenia porządkowego obowiązków, może być to zatem w każdej prawnie dopuszczalnej formie, jako najpowszechniejsze będzie podanie treści rozporządzenia w lokalnej oraz regionalnej prasie, radiu, jak też telewizji, może to być też forma obwieszczeń i ogłoszeń w urzędach gminy, starostwach powiatowych oraz urzędzie wojewódzkim i marszałkowskim. Determinantem nie jest forma ogłoszenia a powszechna dostępność do takiego rozporządzenia.

\section{Zakończenie}

Od państwa demokratycznego wymagać należy, aby było państwem sprawnym, zatem skutecznie realizującym swoje podstawowe funkcje określone przepisami obowiązującego prawa związku z powyższym przepisy prawne muszą regulować funkcjonowanie organów władzy publicznej w warunkach kryzysu 
i zagrożenia (sytuacjach nadzwyczajnych). Jest to o tyle ważne, że może istnieć konieczność podjęcia głębokiej ingerencji w sferę wolności i praw jednostki, która jest konieczna w celu odparcia zagrożenia ${ }^{18}$. Takim organem, który powinien skutecznie wykonywać powierzone zadania w zakresie bezpieczeństwa i porządku publicznego, czy też zapobiegania zagrożeniu życia i zdrowia ma być wojewoda. Regulacje prawne w tym przedmiocie nie nadążają jednak nie tylko za dynamiką i różnorodnością zagrożeń, ale też nie są spójne, jeżeli chodzi o wojewódzki system bezpieczeństwa narodowego.

Doktryna postuluje uczynienie wojewody współodpowiedzialnym nie tylko za stan administracji rządowej do działania, ale też za realny poziom bezpieczeństwa i porządku publicznego w województwie. Obecny stan rzeczy może się nie przyczyniać do zwiększenia aktywności w tym zakresie $^{19}$. Nie jest to jednak takie oczywiste ze względu na zasadę decentralizacji administracji publicznej i ważne miejsce samorządu terytorialnego, jakie zajmuje on w sferze bezpieczeństwa. Zasada decentralizacji „rozczłonkowuje” system bezpieczeństwa narodowego w terenie, ograniczając tym samym właściwe mechanizmy kierownicze, a nawet koordynacyjne w tym zakresie ${ }^{20}$. Wojewoda nie może ingerować w konstytucyjnie zagwarantowaną swobodę samorządu terytorialnego, nawet w sprawach bezpieczeństwa. Posiada on instrumentarium nadzorcze, którego uruchomienie zdeterminowane jest kryterium zgodności prawem. Jeżeli samorząd terytorialny prawa nie narusza wojewoda nie ma konstytucyjnego upoważnienia do władczego wkraczania w jego sprawy. Takie wartości jak bezpieczeństwo, porządek publiczny, czy zapobieganie zagrożeniu życia i zdrowia, same w sobie nie stanowią podstawy pozwalającej wojewodzie władczo oddziaływać na samorząd terytorialny, może on ingerować dopiero, gdy dochodzi do naruszenia prawa. Przedstawiciel Rady Ministrów w terenie nie może też kierować podmiotami niezależnymi, jakimi są jednostki samorządu terytorialnego, ograniczając tym samym ich konstytucyjnie zagwarantowaną swobodę i których samodzielność jest sądownie chroniona, ponieważ godzi to w zasadę decentralizacji administracji publicznej

${ }^{18}$ K. Prokop, Administracja publiczna w obliczu „sytuacji nadzwyczajnej” na tle aktualnych przepisów konstytucyjnych i ustawowych, [w:] M. Ciecierski, M. Czuryk, M. Karpiuk (red.), Zakres działania administracji publicznej w Polsce i na Ukrainie. Wybrana problematyka, Warszawa-Kijów 2016, s. 23.

${ }_{19}$ J. Dobkowski, P. Sobotko, Rola wojewody w systemie reagowania na zagrożenia terrorystyczne, „Studia Prawnoustrojowe” 2016, nr 32, s. 39.

${ }^{20}$ M. Karpiuk, Zarys koncepcji terenowego systemu bezpieczeństwa narodowego, [w:] W. Kitler, K. Drabik, I. Szostek (red.), System bezpieczeństwa narodowego RP. Wybrane problemy, Warszawa 2014, s. 320. 


\section{Bibliografia}

Czuryk M., Karpiuk M., Mazuryk M. (red.), Ustawa o wojewodzie i administracji rzq̨dowej w województwie. Komentarz, Warszawa 2012.

Dobkowski J., Sobotko P., Rola wojewody w systemie reagowania na zagrożenia terrorystyczne, "Studia Prawnoustrojowe" 2016, nr 32.

Dunaj K., Zarządzanie kryzysowe na poziomie wojewódzkim, [w:] M. Czuryk, K. Dunaj, M. Karpiuk, K. Prokop, Prawo zarządzania kryzysowego. Zarys systemu, Olsztyn 2016.

Karpiuk M., Zadania i kompetencje zespolonej administracji rzq̨dowej w sferze bezpieczeństwa narodowego Rzeczypospolitej Polskiej. Aspekty materialne i formalne, Warszawa 2013.

Karpiuk M., Zarys koncepcji terenowego systemu bezpieczeństwa narodowego, [w:] W. Kitler, K. Drabik, I. Szostek (red.), System bezpieczeństwa narodowego RP. Wybrane problemy, Warszawa 2014.

Lis W., Bezpieczeństwo wewnętrzne i porządek publiczny jako sfera działania administracji publicznej, Lublin 2015.

Pacak M., Zmorek K., Ustawa o wojewodzie i administracji rzq̨dowej w województwie. Komentarz Warszawa 2013.

Pawełczyk M. , Sokal P., Ustawa o zarządzaniu kryzysowym. Komentarz, Warszawa 2014.

Poździoch S. (red.), Ustawa o państwowym ratownictwie medycznym. Komentarz, Warszawa 2013.

Prokop K., Administracja publiczna w obliczu "sytuacji nadzwyczajnej" na tle aktualnych przepisów konstytucyjnych i ustawowych, [w:] M. Ciecierski, M. Czuryk, M. Karpiuk (red.), Zakres działania administracji publicznej w Polsce i na Ukrainie. Wybrana problematyka, Warszawa-Kijów 2016.

\section{Streszczenie:}

Jedną ze sfer, w ramach których administracja publiczna wykonuje swoje zadania jest bezpieczeństwo. Do katalogu organów administracji publicznej, wyposażonych w środki oddziałujące na bezpieczeństwo i z nim związane - porządek publiczny, ochrona życia i zdrowia, należy również wojewoda. Podejmuje on działania w zakresie przeciwdziałania sytuacjom nadzwyczajnym, ich zwalczania oraz usuwania skutków, które w związku z nimi zaistniały. Ze względu na konieczność dostosowania działań ochronnych do zagrożenia oraz potrzebę ich harmonizacji, wojewoda może również, w przypadkach ustawowo przewidzianych, podejmować czynności kierownicze i koordynacyjne na obszarze regionu. Jest on organem, który posiada szerokie kompetencje pozwalające mu kształtować terenowy system bezpieczeństwa na poziomie wojewódzkim.

Słowa kluczowe: wojewoda, bezpieczeństwo, porządek publiczny, ochrona życia, ochrona zdrowia.

\section{Jurisdiction of the voivodeship governor in ensuring security and public order as well as preventing threats to life and health}

\section{Summary:}

One of the fields in which public administration performs its task is security. The voivodeship governor is a part of public administration as they are equipped with security measures related to public order and the protection of life and health. They undertake actions to prevent, control and deal with extraordinary situations and their consequences. Due to the need to adapt protective measures to the threat and the need to harmonize them, in cases provided by the law, the governor may also undertake managing and coordinating activities in the area of the region. It is a body that has broad competencies to shape the field safety system at the voivodeship level.

Keywords: voivodeship governor, security, public order, life protection, health protection 